\title{
Seasonal abundance of zooplankton and growth performance of prawn and fish in ponds of Rajshahi
}

MAB Siddique, M Afzal Hussain*, MA Hossain and M Manjurul Alam

Department of Fisheries, University of Rajshahi, Rajshahi-6205, Bangladesh

*Dr. M. Afzal Hussain, Associate Professor, Department of Fisheries, University of Rajshahi, Rajshahi-6205, Bangladesh.E-mail: afzalh_ru@yahoo.com / Tel: 88-0721-750041-49 Ext. 4117(Off)/Fax: 88-0721-750064

\begin{abstract}
The present study was conducted on seasonal abundance of phytoplankton of prawn based carp polyculture system fishponds for a period of six months from September 2006 to February in the village Meherchandi of Boalia thana under Rajshahi district of Bangladesh. During the study period, it was found that water temperature varied from $16.59^{\circ} \mathrm{C}\left(\mathrm{T}_{2}\right)$ to $29.82\left(\mathrm{~T}_{1}\right)$, transparency $26.72\left(\mathrm{~T}_{1}\right)$ to $40.13 \mathrm{~cm}\left(\mathrm{~T}_{2}\right), \mathrm{pH} 7.21\left(\mathrm{~T}_{1}\right)$ to $8.0\left(\mathrm{~T}_{2}\right)$ DO $2.13\left(\mathrm{~T}_{2}\right)$ to $3.6 \mathrm{mg} / \mathrm{l}\left(\mathrm{T}_{2}\right), \mathrm{CO}_{2}$ $4.63\left(T_{1}\right)$ to $10.63 \mathrm{mg} / \mathrm{l}\left(\mathrm{T}_{2}\right), \mathrm{NH}_{3} \mathrm{~N} 0.001\left(\mathrm{~T}_{1}\right)$ to $0.0197 \mathrm{mg} / \mathrm{l}\left(\mathrm{T}_{2}\right)$ and total alkalinity fluctuated from $85.38\left(T_{1}\right)$ to $147.75 \mathrm{mgl}\left(\mathrm{T}_{2}\right)$. A total four groups of zooplankton were identified where 5 rotifera (38.41\%) was dominant followed by 3 cladocera (31.49\%), 2 copepoda (21.84\%) and crustacean larvae (8.26\%). It was also found that zooplankton showed abundance in February. The highest total average zooplankton (18390.79 \pm 2144.63 cells/l) was recorded in $T_{1}$ than $T_{2}$ which might be due to the effective uses by high stocking density of fishes. Zooplankton showed positive correlation with $\mathrm{pH}, \mathrm{DO}, \mathrm{CO}_{2}$ and alkalinity in $\mathrm{T}_{1}$. In case of $\mathrm{T}_{2}$, positive co-relationship was found with $\mathrm{pH}, \mathrm{DO}, \mathrm{CO}_{2}$ and $\mathrm{NH} 3-\mathrm{N}$. The mean values of highest final weight of $M$. rosenbergii, $H$. molitrix and $C$. catla were $89.20 \pm 8.62 \mathrm{~g}\left(\mathrm{~T}_{1}\right), 682.70 \pm 44.20 \mathrm{~g}\left(\mathrm{~T}_{2}\right)$ and $428.00 \pm 4.50 \mathrm{~g}\left(\mathrm{~T}_{1}\right)$ respectively, highest survival rate was found $76.25 \pm 6.25 \%\left(T_{1}\right)$ of prawn and highest total average yield was obtained $940.65 \pm 259.43 \mathrm{~kg} / \mathrm{ha}$ in $\mathrm{T}_{2}$ due to high stocking densities of prawn.
\end{abstract}

Key words: Zooplankton abundance, physico-chemical parameters, carp polyculture, growth performance

\section{Introduction}

The role of plankton in a water body of the sources of foods for fishes has been well recognized. Because plankton is the natural food of many species of fishes, especially zooplankton constitute important food items of many omnivorous and carnivorous fishes. The larvae of carps feed mostly on zooplankton (Dewan et al., 1977). According to Prasad \& Singh (2003), the zooplankton forms the principal sources of food for fish within the water body. Bhuiyan \& Islam (1988) observed that zooplankton also plays a very important role in the food chain as they are in the second trophic level as primary consumer and also as contributors to the next trophic level. Seasonal abundance of plankton in a fish pond are of great importance for any type of aquaculture operation, as they vary from water quality of culture ponds, location to location and within similar ecological conditions (Boyd, 1982). Among the different types of culture systems, the semi-intensive aquaculture is common practice in Bangladesh. That's why a large number of research works has conducted on the ecology of zooplankton population from different waters body of carp polyculture fish ponds such Khan et al.
(1978), Bhuiyan \& Nesa (1998a \& 1998b), Islam et al. (2000), Chowdhury \& Mamun (2006), Rahman \& Hossain (2008) and many researchers worked on the percentage composition, seasonal variation and occurrence of freshwater zooplankton. But, until now no systematic investigation was done on the zooplankton abundance of prawn based carp polyculture fish pond in Rajshahi region. Therefore, the present investigation has been undertaken on related to the title.

\section{Materials and Methods}

\section{Location of study area and descriptions of ponds}

The present study was conducted in the village Meherchandi of Boalia Thana under Rajshahi district for a period of 6 months from September 2006 to February 2007. For this study, four ponds were selected under two treatments with an average area of 0.34 ha and depth of $1 \mathrm{~m}$. The ponds were rectangular in shape, well exposed to sunlight, independent and completely free from aquatic vegetation. 


\section{Experimental design and pond preparation}

The present experiment was conducted with two treatments each with two replications and every treatment was designed with $M$. rosenbergii, $H$. molitrix and $C$. catla. The stocking density of carp in each treatment was fixed $(H$. molitrix-2968/ha C. catla-1976/ha) but the stocking density of prawn was at the rate of $40 / 40 \mathrm{~m}^{2}(9880 / \mathrm{ha})$ in Treatment $1\left(T_{1}\right)$ and at the rate of $60 / 40 \mathrm{~m}^{2}$ $(14820 / \mathrm{ha})$ in treatment $2\left(T_{2}\right)$. During the study period, all the ponds were limed at the dose of $250 \mathrm{~kg} / \mathrm{ha}$ after removal of aquatic weeds and unwanted species and fertilized with cowdung$2470 \mathrm{~kg} / \mathrm{ha}$, urea-50kg/ha and TSP-50 kg/ha before stocking. Shelter or refuges was made for prawn by the uses of dried branches of bamboo which covered minimum 5\% area of each pond. After seven days of fertilization all the ponds were stocked with specific species and initial average length, weights and sizes of each species of fishes and prawns were recorded before realizing. Post stocking fertilization was made (cow dung$50 \mathrm{~kg} / \mathrm{ha}$, urea-1.25kg/ha and TSP-1.25kg/ha) as daily basis. The supplementary feeds were applied twice daily for fish species with same feeding formulation (rice bran $20 \%+$ mustard oil cake $50 \%+$ fish meal $30 \%$ ) at the rate of $5 \%$ of fish. The daily ration was adjusted based on the determination of total biomass through monthly sampling.

\section{Study of parameters}

The physico-chemical parameters were done fortnightly (8:30-9:30am). A centigrade thermometer used to recorded water temperature $\left({ }^{\circ} \mathrm{C}\right)$. Measurement of water transparency $(\mathrm{cm})$ was done by a secchi disc of $15.5 \mathrm{~cm}$ diameter. $\mathrm{pH}$ was measured by a pH indicator paper (LOGAK, Korea). DO was determined by the Winkler's titration method (APHA, 1989). Free $\mathrm{CO}_{2}, \mathrm{NH}_{3}-\mathrm{N}$ and total alkalinity was determined according to Welch (1948).

\section{Study of zooplankton}

For zooplankton study, 20 liters of water sample from each pond was collected (8:30-9:30am) in a plastic bucket fortnightly and passed through plankton net of $55 \mu$ mesh size. Then the concentrated plankton samples were preserved in plastic vials with $5 \%$ formalin for subsequent studies. For the qualitative and quantitative study of plankton, $1 \mathrm{ml}$ of the concentrated samples was taken by a dropper and then put on the S-R (Sedgwick-Rafter) counting chamber as described by Stirling (1985). Zooplankton were identified up to genus level following keys were given by Ward and Whipple (1954), \& Needham \& Needham (1962).

\section{Study of growth performance}

Final weight (g), survival rate (\%) and yield (kg/ha) of prawn silver carp and catla was estimated. Survival rate and yield were estimated using the following formula

Survival rate $(\%)=\frac{\text { No. of fish harvested }}{\text { No. of fish stocked }} \times 100$

Yield $/$ production $=$ No. of fish harvested $\times$ final weight of fish.

Statistical analysis was done through SPSS programme and means were also compared to see the significant difference.

\section{Results and Discussion}

Water quality parameters: During the study period some selected physico-chemical parameters were studied which are shown in the Table 1. It was found that highest water temperature was found $29.82^{\circ} \mathrm{C}$ (September '06) in $\mathrm{T}_{1}$ and lowest was $16.59^{\circ} \mathrm{C}$ (February '07) in $\mathrm{T}_{2}$. Transparency was observed to be lowest $(26.72 \mathrm{~cm})$ in February ' 07 in $\mathrm{T}_{1}$ and highest $(40.13 \mathrm{~cm})$ in December ' 06 in $T_{2}$. The pond water of both treatments showed alkaline condition. The highest $\mathrm{pH}$ was noted (8.0) in February ' 07 in $\mathrm{T}_{2}$ and lowest was 7.21(October '06) in $\mathrm{T}_{1}$. The lowest and highest dissolved oxygen content of water varied 2.13 (October' 06) to $3.6 \mathrm{mg} / \mathrm{l}$ (September' 06) which was recorded in $T_{2}$. Free carbon dioxide showed maximum $(10.63 \mathrm{mg} / \mathrm{l})$ in $\mathrm{T}_{2}$ in February'07 and minimum $(4.63 \mathrm{mg} / \mathrm{l})$ in September '06 in $\mathrm{T}_{1} . \mathrm{NH}_{3} \mathrm{~N}$ varied from 0.001 (November' 06 and February '06) to $0.02 \mathrm{mg} / \mathrm{l}$ (September '06) in $T_{1}$ and $T_{2}$ respectively. The total alkalinity fluctuated from 85.38 (September' 06) to $147.75 \mathrm{mgl}$ (September 06) where highest and lowest was recorded in $T_{1}$ and $T_{2}$ respectively. During the study period it was also found that the mean values of different water quality parameters were with the acceptable ranges (Table 1). Hoq et al. (1996) and Ling (1969) reported that the water temperature ranged from 27.5 to $30.5^{\circ} \mathrm{C}$ and 22 to $32^{\circ} \mathrm{C}$ was suitable for the growth of prawn and the present finding almost similar with findings of Hossain \& Akhteruzzaman (2007). Secchi disc reading was lower in $T_{1}$ and high in $T_{2}$. However the ranges of secchi disc reading were found favorable for carp-prawn culture (Hossain et al., 2002) who recommended 35 to $60 \mathrm{~cm}$ water transparency for prawn farming. $\mathrm{pH}$ values 6.5 to 9.0 (Swingle, 1967) and 6.9 to 8.8 (Chiu, 1987) noted that optimum range for prawn culture. The best range of water $\mathrm{pH}$ for shrimp culture is 7-9 (Boyd \& Faust, 1992). Therefore, the mean value of $\mathrm{pH}$ was found within 
the suitable range according to the aforesaid scientists. Comparatively lower value of DO might be associated to the decomposition of unused feed and excreta of the fish (Boyd, 1998). The present findings more or less similar with the findings of Hoq et al. (1996) who reported DO ranged from 4.0 to 5.9 $\mathrm{mg} / \mathrm{l}$ for prawn farming and $\mathrm{CO}_{2}$ below $12 \mathrm{mg} / \mathrm{l}$ is suitable for fish culture (Boyd, 1998). The value of
$\mathrm{NH}_{3}-\mathrm{N}$ was in suitable range for fish culture and which is almost similar with findings of Boyd (1998) who suggested keeping the ammonia-nitrogen value lees than $0.1 \mathrm{mg} / \mathrm{l}$. Singh \& Singh (1975) concluded that alkalinity range from $30-125 \mathrm{mg} / \mathrm{l}$ is favorable for fish growth and the present finding is strongly agreed with the findings of New and Singholka (1985).

Table 1. Monthly variation of water quality parameters of pond-1 and pond-2 (September, 2006 to February, 2007)

\begin{tabular}{|c|c|c|c|c|c|c|c|c|c|c|c|c|c|c|}
\hline \multirow[t]{2}{*}{ Months } & \multicolumn{2}{|c|}{$\begin{array}{c}\text { Temperature } \\
\left({ }^{\circ} \mathrm{C}\right)\end{array}$} & \multicolumn{2}{|c|}{$\begin{array}{c}\text { Transparency } \\
(\mathrm{cm})\end{array}$} & \multicolumn{2}{|c|}{$\mathrm{pH}$} & \multicolumn{2}{|c|}{$\begin{array}{c}\mathrm{DO} \\
(\mathrm{mg} / \mathrm{l})\end{array}$} & \multicolumn{2}{|c|}{$\begin{array}{c}\mathrm{CO}_{2} \\
(\mathrm{mg} / \mathrm{l}) \\
\end{array}$} & \multicolumn{2}{|c|}{$\begin{array}{l}\mathrm{NH}_{3}-\mathrm{N} \\
(\mathrm{mg} / \mathrm{l})\end{array}$} & \multicolumn{2}{|c|}{$\begin{array}{c}\text { Alkalinity } \\
(\mathrm{mg} / \mathrm{l})\end{array}$} \\
\hline & $\mathrm{T}_{1}$ & $\mathrm{~T}_{2}$ & $\mathrm{~T}_{1}$ & $\mathrm{~T}_{2}$ & $\mathrm{~T}_{1}$ & $\mathrm{~T}_{2}$ & $\mathrm{~T}_{1}$ & $\mathrm{~T}_{2}$ & $\mathrm{~T}_{1}$ & $\mathrm{~T}_{2}$ & $\mathrm{~T}_{1}$ & $\mathrm{~T}_{2}$ & $\mathrm{~T}_{1}$ & $\mathrm{~T}_{2}$ \\
\hline Sep'06 & 29.82 & 29.59 & 32.63 & 38.94 & 7.41 & 7.38 & 3.10 & 3.6 & 4.63 & 6.00 & 0.004 & 0.019 & 85.38 & 147.75 \\
\hline Oct'06 & 28.16 & 29.07 & 31.5 & 32.55 & 7.21 & 7.53 & 2.79 & 2.13 & 8.38 & 6.63 & 0.012 & 0.018 & 94.13 & 104.25 \\
\hline Nov'06 & 24.21 & 24.10 & 34.69 & 38.32 & 7.57 & 7.59 & 3.38 & 2.96 & 6.38 & 7.13 & 0.001 & 0.019 & 97.38 & 102.75 \\
\hline Dec'06 & 18.23 & 18.59 & 35.63 & 40.13 & 7.49 & 7.64 & 3.26 & 2.99 & 7.63 & 7.64 & 0.04 & 0.019 & 93.25 & 113.88 \\
\hline Jan'07 & 18.88 & 19 & 27.82 & 33.32 & 7.67 & 7.63 & 2.56 & 2.93 & 9.38 & 9.50 & 0.011 & 0.019 & 92.75 & 110.75 \\
\hline Feb'08 & 16.75 & 16.59 & 26.72 & 27.68 & 7.89 & 8.00 & 2.98 & 2.84 & 9.63 & 10.63 & 0.001 & 0.015 & 122.38 & 123.13 \\
\hline Mean & 22.68 & 22.82 & 31.50 & 35.16 & 7.54 & 7.63 & 3.04 & 2.91 & 7.75 & 7.92 & 0.012 & 0.018 & 97.55 & 117.09 \\
\hline$\pm \mathrm{SD}$ & \pm 5.53 & \pm 5.61 & \pm 3.60 & \pm 4.80 & \pm 0.23 & \pm 0.21 & \pm 0.29 & \pm 0.47 & \pm 1.95 & \pm 178 & \pm 0.01 & \pm 0.00 & \pm 12.79 & \pm 16.72 \\
\hline $\begin{array}{c}\text { Acceptable } \\
\text { range }\end{array}$ & & & & & & & & 7 & $R$ & 12 & $\mathrm{Be}$ & 0.0 & & 00 \\
\hline
\end{tabular}

The occurrence (\%) of different zooplankton groups: The occurrences (\%) of different groups of zooplankton with genera under different treatments are shown in Table 2 and Fig 1. Dominance of different groups and genera were identified on the basis of presence in both treatments. During the present study, a total of 10 genera under 3 groups of zooplankton were identified where 5 rotifera (38.41\%) was dominant group (Brachionus $>$ Keratella $>$ Notholca $>$ Asplanchna >Filinia) followed by 3 cladocera (31.49\%, Daphnia >Moina> Diaphanosoma), 2 copepoda
(2184\%, Cyclops>Diaptomus), and crustacean larvae constitutes $8.26 \%$ of total zooplankton groups. Rahman \& Hossain (2008) study on four groups of zooplankton of culture and non culture fishponds and recorded that 2 copepods constituted 30.47 to $43.39 \%, 4$ rotifers constituted 19.17 to $21.67 \%$, 3 cladocera constituted 17.54 to $27.09 \%$ and crustacean larvae constituted 15.28 to $19.91 \%$ in total zooplankton population. These findings are in good agreement with Hossain \& Akhterruzzaman (2007).

Table 2. The occurrence (\%) of different groups of phytoplankton with genera under different treatments during the study period

\begin{tabular}{|c|c|c|c|c|}
\hline \multirow{2}{*}{$\begin{array}{c}\text { Serial } \\
\text { No. }\end{array}$} & \multirow{2}{*}{ Zooplankton groups } & \multirow{2}{*}{ Genus } & \multicolumn{2}{|c|}{$\%$ of genus } \\
\hline & & & $\mathrm{T}_{1}$ & $\mathrm{~T}_{2}$ \\
\hline \multirow{2}{*}{1} & Copepoda & Cyclops & 55.35 & 59.92 \\
\hline & $(21.84 \%)$ & Diaptomus & 44.65 & 40.08 \\
\hline \multirow{5}{*}{2} & \multirow{5}{*}{$\begin{array}{c}\text { Rotifera } \\
(38.41 \%)\end{array}$} & Notholca & 15.85 & 17.39 \\
\hline & & Keratella & 24.18 & 19.22 \\
\hline & & Brachionus & 40.28 & 37.4 \\
\hline & & Filinia & 10.28 & 9.12 \\
\hline & & Asplanchna & 9.41 & 16.87 \\
\hline \multirow{3}{*}{3} & \multirow{3}{*}{$\begin{array}{c}\text { Cladocera } \\
(31.49 \%)\end{array}$} & Moina & 34.77 & 38.46 \\
\hline & & Daphnia & 44.85 & 41.33 \\
\hline & & Diaphanosoma & 20.38 & 20.21 \\
\hline 4 & plius (8.26\%) & & 100.00 & 100.00 \\
\hline
\end{tabular}




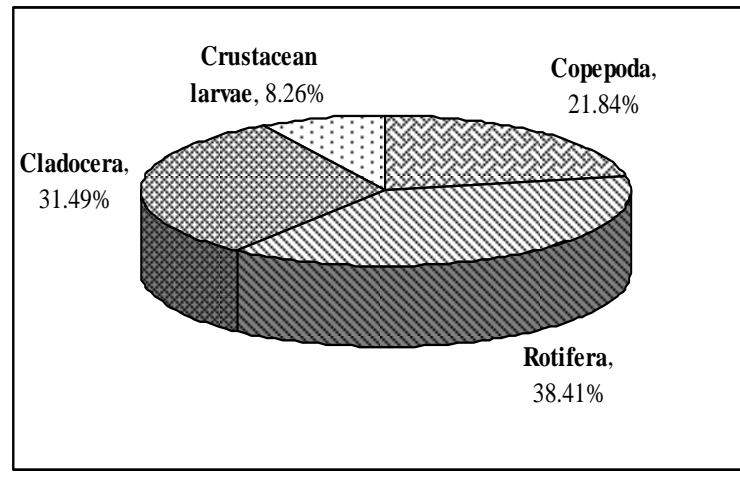

Fig 1. The occurrence (\%) of different groups zooplankton

Seasonal abundance of zooplankton groups: Monthly abundance of different zooplankton groups under different treatments are shown in Table 3 and Fig 2 and 3. . It was found that the highest concentration of copepoda was found 6851.25 cells/l (February, 2007) and lowest value was recorded 2542.50 cells/l (September, 2006) in $T_{1}$. The concentration of rotifera varied from 4050.00 to 11812.50 cells/l where highest was recorded in $\mathrm{T}_{1}$ (February'07) and lowest was recorded in $T_{2}$ (October, 2006). The highest concentration of cladocera (8268.75 cells/l) was recorded in $T_{1}$ (February, 2007) and lowest
(2531.25 cells/l) was recorded in $\mathrm{T}_{2}$ (October, 2006). The highest and lowest value of crustacean larvae varied from 3746.25 to 697.50 cells/l in $T_{1}$ and $T_{2}$ respectively where highest was recorded in February, 2007 and lowest was recorded in September, 2006. During the study period it was also found that highest total average zooplankton (18390.79 \pm 2144.63 cells/l) was recorded in $T_{1}$ than $T_{2}$ which might be due to the effective uses by high stocking density of fish (Table 3). Rahman \& Hossain (2008) found peak season of copepods in September, rotifers cladocerans and crustacean larvae were dominant in January. Das \& Srivastava (1956) divided their entire investigation year into various dominant periods such as September, October and November constituted the copepodan period, December and January were characterized by cladocerans and April, May and June were characterized by crustacean larvae. From the study, it was observed that zooplankton showed peak in January to February. Bhuiyan \& Nessa (1998a,b) and Islam et al. (2000) recorded highest density of zooplankton in January (42213units/l and 1350units/l respectively). The present finding is almost similar with the findings of Hossain \& Akhterruzzaman (2007).

Table 3. Monthly abundance of different zooplankton groups under different treatments

\begin{tabular}{|c|c|c|c|c|c|c|c|}
\hline \multirow{2}{*}{ Zooplankton groups } & \multicolumn{6}{|c|}{ Zooplankton concentration (cells/l) } & \multirow{2}{*}{$\begin{array}{l}\text { Groups } \\
\text { total (cells/l) }\end{array}$} \\
\hline & Sep’06 & Oct'06 & Nov'06 & Dec'06 & Jan'07 & Feb'07 & \\
\hline \multicolumn{8}{|l|}{ Treatment 1} \\
\hline Copepoda & 2542.50 & 3208.75 & 3307.50 & 3780.00 & 5298.75 & 6851.25 & \multirow{5}{*}{$\begin{array}{l}18390.79 \\
\pm 2144.63\end{array}$} \\
\hline Rotifera & 4736.25 & 4387.50 & 5332.50 & 7728.75 & 8845.00 & 11812.5 & \\
\hline Cladocera & 2995.00 & 2767.50 & 4185.00 & 6378.75 & 7240.00 & 8268.75 & \\
\hline Crustacean larvae & 832.50 & 971.00 & 1113.75 & 2362.50 & 1552.50 & 3746.25 & \\
\hline Total & 11106.25 & 11334.75 & 13938.75 & 20250.00 & 22936.25 & 30678.75 & \\
\hline \multicolumn{8}{|l|}{ Treatment 2} \\
\hline Copepoda & 2812.50 & 3105.00 & 3780.00 & 4353.75 & 4387.50 & 5533.75 & \multirow{5}{*}{$\begin{array}{l}17195.04 \\
\pm 1830.18\end{array}$} \\
\hline Rotifera & 4183.75 & 4050.00 & 5737.50 & 8842.50 & 6506.25 & 9888.75 & \\
\hline Cladocera & 2812.50 & 2531.25 & 3876.25 & 7089.00 & 6850.25 & 7188.75 & \\
\hline Crustacean larvae & 697.50 & 945.00 & 843.75 & 3003.50 & 1856.25 & 2295.00 & \\
\hline Total & 10508.25 & 10631.25 & 14237.50 & 23288.75 & 19600.25 & 24906.25 & \\
\hline
\end{tabular}




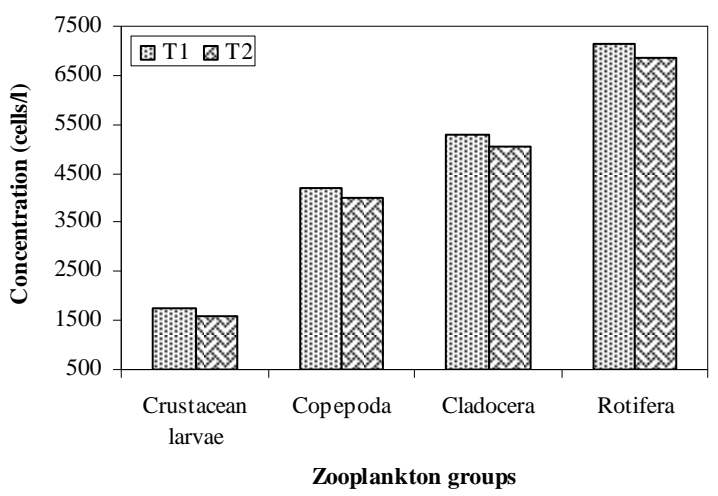

Fig 2. Mean concentration of different groups of zooplankton of $T_{1}$ and $T_{2}$

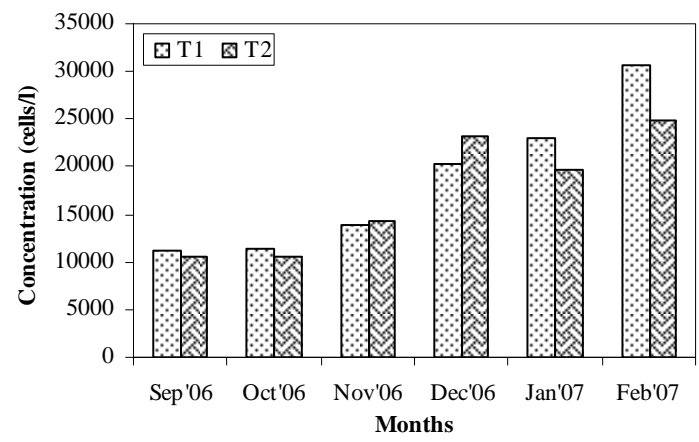

Fig 3. Monthly abundance of zooplankton of $T_{1}$ and $\mathrm{T}_{2}$

\section{Correlation between water quality parameters and zoooplankton}

It was found that zooplankton showed positive correlation with $\mathrm{pH}(\mathrm{r}=0.859), \mathrm{DO}(\mathrm{r}=0.352), \mathrm{CO}_{2}$ $(r=0.838)$ and alkalinity $(r=0.656)$ where negative co-relationship was found with water temperature and transparency in $T_{1}$ (Table 4). In case of $T_{2}$, positive co-relationship was found with $\mathrm{pH}$ $(r=0.686)$ DO ( $r=0.045), \mathrm{CO}_{2}(r=0.787)$ and NH3-N $(r=0.248)$ where negative co-relationship was found with other observed parameters. Rahman \& Hossain (2008) found that zooplankton showed significant positive correlation with $\mathrm{pH}, \mathrm{DO}$ and $\mathrm{CO}_{2}$. Miah et al. (1981) and Alam et al. (1987), zooplankton showed positive correlation with $\mathrm{CO}_{3}{ }^{-}$ and $\mathrm{HCO}_{3}^{-}$alkalinity. Patra \& Azadi (1987) reported that inverse relationship existed between zooplankton and water temperature which is strongly support the present study.

\section{Growth performance of prawn and fish}

Final weight, survival rate and yield of different fish species under different treatments are shown in Table 5. During the study period maximum final weight $(\mathrm{g})$ of $M$. rosenbergii, $H$. molirix, and $C$. catla was recorded as $89.20\left(\mathrm{~T}_{1}\right), 672.70\left(\mathrm{~T}_{2}\right)$ and $428.00\left(T_{1}\right)$ respectively. The present result is more or less similar with the findings of Sadek and

Table 4. Relationship between water quality parameters and zooplankton under different treatments during the study period

\begin{tabular}{l|c|c}
\hline \multirow{2}{*}{ Water quality parameters } & \multicolumn{3}{|c}{ Zooplankton } \\
\cline { 2 - 3 } & $\mathrm{T}_{1}$ & $\mathrm{~T}_{2}$ \\
\hline Temperature $\left({ }^{\circ} \mathrm{C}\right)$ & -0.905 & -0.865 \\
Transparency $(\mathrm{cm})$ & -0.536 & -0.071 \\
$\mathrm{pH}$ & 0.859 & 0.686 \\
$\mathrm{DO}(\mathrm{mg} / \mathrm{l})$-morning & 0.352 & 0.045 \\
$\mathrm{Free} \mathrm{CO}_{2}(\mathrm{mg} / \mathrm{l})$ & 0.838 & 0.787 \\
$\mathrm{NH}_{3}-\mathrm{N}(\mathrm{mg} / \mathrm{l})$ & -0.312 & 0.248 \\
Alkalinity $(\mathrm{mg} / \mathrm{l})$ & 0.656 & -0.120 \\
\hline
\end{tabular}

El-Gayar (1993), Islam et al. (1999) and Chand et al. (2002). The highest value of survival rate (\%) was recorded as $76.25\left(T_{1}\right), 74.99\left(T_{1}\right)$ and 68.75 $\left(T_{2}\right)$ for these species respectively, which was higher than the findings of Alam et al. (2001) who recorded $62.50 \%$ survival rate of $M$. rosenbergii and $96.42 \%$ of $H$. molitrix. Chand et al. (2002) recorded $65-66 \%$ survival rate of $C$. catla. and the maximum yield $(\mathrm{kg} / \mathrm{ha})$ was recorded as 851.53 $\left(T_{2}\right), 1496.60\left(T_{1}\right)$ and $542.53\left(T_{2}\right)$ where total highest average yield $(\mathrm{kg} / \mathrm{ha})$ was recorded for these species as 940.65 in $\mathrm{T}_{2}$ due to high stocking density of prawn. Chand et al. (2002) recorded the yield 229 and $622 \mathrm{~kg} / \mathrm{ha}$ for the M. rosenbergii and C. catla, respectively. In case of $H$. molitrix, Islam et al. (1999) recorded yield $927.15 \mathrm{~kg} / \mathrm{ha}$. 
Table 5. Variation in the mean values of final weight, survival rate and yield of different fish species under different treatments

\begin{tabular}{|c|c|c|c|c|c|c|c|}
\hline \multirow{2}{*}{ Species } & \multicolumn{2}{|c|}{ Final weight (g) } & \multicolumn{2}{|c|}{ Survival rate (\%) } & \multicolumn{2}{|c|}{ Yield (kg/ha) } & \multirow{2}{*}{\begin{tabular}{|c|} 
Level of \\
significance
\end{tabular}} \\
\hline & $\mathrm{T}_{1}$ & $\mathrm{~T}_{2}$ & $\mathrm{~T}_{1}$ & $\mathrm{~T}_{2}$ & $\mathrm{~T}_{1}$ & $T_{2}$ & \\
\hline \multirow{2}{*}{ M. rosenbergii } & 89.20 & 80.03 & 76.25 & 71.65 & 677.27 & 851.53 & \multirow{2}{*}{ NS } \\
\hline & \pm 8.62 & \pm 6.38 & \pm 6.25 & \pm 1.65 & \pm 119.98 & \pm 87.48 & \\
\hline \multirow[b]{2}{*}{ H. molitrix } & 675.50 & 682.70 & 74.99 & 70.83 & 1496.60 & 1427.87 & \multirow{2}{*}{ NS } \\
\hline & \pm 21.75 & \pm 44.20 & \pm 8.33 & \pm 4.17 & \pm 118.54 & \pm 8.47 & \\
\hline \multirow{2}{*}{ C. catla } & 428.00 & 398.60 & 62.50 & 68.75 & 529.99 & 542.53 & \multirow{2}{*}{ NS } \\
\hline & \pm 4.50 & \pm 8.40 & \pm 12.50 & \pm 6.25 & \pm 111.57 & \pm 60.64 & \\
\hline \multirow{2}{*}{\multicolumn{3}{|c|}{ Total average yield }} & & & 901.29 & 940.65 & \multirow[t]{2}{*}{ NS } \\
\hline & & & & & \pm 300.68 & \pm 259.43 & \\
\hline
\end{tabular}

NS=Non significant

\section{References}

Alam, A.K.M.N., Islam, M.A., Mollah, M.F.A. \& Haq, M.S. 1987. Status of zooplankton in newly constructed ponds and their relations to some meteorological and limnological factors. Bangladesh J. Fish. 10(1):83-88.

Alam, M.J., Jahan, D.A., Pramanik, W.A. \& Hoq, M.E. 2001. Polyculture of freshwater prawn, Macrobrachium rosenbergii (de man) with carps: effects of prawn stocking density. Bangladesh $\mathrm{J}$. Fish. Res. 5(2):135-143.

APHA, 1989. Standard methods for the examination of water and waste water (4th ed.) American Public Health Association, Washington. 1125pp.

Bhuiyan, A.S. \& Islam, M. 1988. Seasonal variation in the percentage composition of the food of Xenontodon cancila. Univ. j. zool. Rajshahi Univ. 7:33-36.

Bhuiyan, A. S. \& Nessa, Q. 1998a. Seasonal variation in the occurrence of some zooplankton in a fish pond. Bangladesh J. Fish. Res. 2(2):201-203.

Bhuiyan, A.S. \& Nessa, Q. 1998b. A quantitative study of zooplankton in relation to the physico-chemical conditions of a freshwater fishpond of Rajshahi. Univ. j. zool. Rajshahi Univ. 17:29-37.

Boyd, C.E. 1982. Water Quality Management for pond fish culture. Elsevier Science Publishers B.V., 1000 Amsterdam, The Netherlands, 318 pp.

Boyd, C.E. 1998. Water Quality for Aquaculture. Research and Development series no. 43. Auburn University, Alabama, USA. 37p.

Boyd, C.E. \& Faust, A.W. 1992. Pond monitoring and management. In: Faust A.W. \& L.J. Lester (eds.). Marine Shrimp Culture: Principles and Practices. Elsevier Science, Amsterdam. pp. 497-508.
Chand, B.K., Patra, B.C. \& Das, S.K. 2002. Growth and production of freshwater prawn and carp under polyculture system. J. Interacademicia. 6(2):210215.

Chiu, Y.N. 1987. Water quality management for intensive prawn culture ponds. In: Edited by Y. N. Chiu, L. M. Santos \& R. O. Juliano, V. P. Technical Consideration for the Management and Operation of Intensive Prawn Farms. Aquaculture Society, Iloilo, Philippines: pp.74-95.

Chowdhury, A.H. \& Mamun, A.A. 2006. Physicochemical conditions and plankton population of two fishponds in Khulna. Univ. J. Zool. Rajshahi Univ. 25: $41-44$.

Das, S.M. \& Srivastava, V.K. 1956. Some new observations on plankton from fresh water ponds and tanks of Lucknow. Indian Sci. Cult. 21(8):466467.

Dewan, S., Ali, M. \& Islam, M.A. 1977. Study on the size and pattern of feeding of fries and fingerlings of three major carps, eg. Labeo rohita (Ham), Catla catla and Cirrhina mrigala. Bangladesh J. Agri. 2(2):223-228.

Hoq, M.E., Islam, M.M. \& Hossain, M.M. 1996. Freshwater prawn (M. rossenbergii) with Chinese and Indian carps in farmers' pond. J. Aqua. Tropics. 11:135-141.

Hossain, M.A. \& Akhteruzzaman, M. 2007. Effect of stocking density on the growth performance of prawn (Macrobrachium rosenbergii) and carp under polyculture system in northern Bangladesh. Int. J. Sustain. Agrid. Tech. 3(5):18-22.

Hossain, M.A., Siddique, M.A.L. \& Miaje, M.A.H. 2002. Development of low-cost feed for culture of giant freshwater prawn (Macrobrachium rosenbergii) in ponds. Bangladesh J. Fish. Res. 4:127-134. 
Islam, M.N., Khan, T.A. \& Bhuiyan, A.S. 2000. Ecology and seasonal abundance of some zooplankton of a pond in Rajshahi. Univ. j. zool. Rajshahi Univ. 19:2532.

Islam, M.R., Saha, S.B., Mollah, M.F.A. \& Rokeya, J.A. 1999. Polyculture of Macrobrachium resenbergii (de man) with carps in ponds. Bangladesh J. Fish. 22(1):39-44.

Jhingran, V. G. 1988. Fish and fishes of India. Hindustan Publishing Corporation (India), Delhi.

Khan, Y.S.A., Salam, A.M.A. \& Ahmed, M.K. 1978. Cladocera of the River Buriganga, Dacca, Bangladesh, Bangladesh J. Zool. 6:73-83.

Ling, S. W. 1969. The general biology and development of $M$. rosenbergii (de Man). FAO Fisheries Report. 3589-3619 pp.

Miah, M.I, Bhuiyan, N.I. \& Dewan, S. 1981. A comparative study of the rate of growth of major carps in relation to physico-chemical and biological factors. Proc. $3^{\text {rd }}$ Nat. Zool. Conf. pp. 215-223.

Needham, J.G. \& Needham, P.R. 1962. A guide to the study of freshwater biology. $5^{\text {th }}$ ed. Liolden-day. Inc. San Francisco. p.106.

New, M. B. \& Singholka, S. 1985. Freshwater prawn farming. A manual for the culture of Macrobrachium rosenbergii. FAO Fisheries Technical Paper (225). Rev. 1: 118 pp.

Patra, R.W.R. \& Azadi, M.A. 1987. Ecological studies on the planktonic organisms of the Halda river. Bangladesh J. Zool. 15(2):109-123.
Prasad, B.B. \& Singh, R.B. 2003. Composition, abundance and distribution of phytoplankton and zoobenthos in a tropical water body. Nat.Envin.Pollut.Technol. 2:255-258.

Rahman, S. \& Hussain, M.A. 2008. A study on the abundance of zooplankton of a culture and a nonculture pond of the Rajshahi University campus. Univ. j. zool. Rajshahi Univ. 27:35-41.

Sadek, S.S. \& El-Gayar, F.M.H. 1993. Production of the giant freshwater prawn Macrobrachium rosenbergii reared in brackish water ponds (Egypt). Proceedings of the first international symposium on aquaculture technology and investment opportunities. Ministry of Agriculture and Water, Riyadh, Saudi Arabia. pp. 296-303.

Singh, C.S. \& Singh, K.P. 1975. Feeding experiments on Indian major carps in Terai ponds. J. Inland Fish Soc. India. 7:212-215.

Stirling, H.P. 1985. Chemical and Biological methods of water analysis for aquaculturists. Institute of Aquaculture, University of Stirling, Scotland. pp 119.

Swingle, H.S. 1967. Relation of $\mathrm{pH}$ of pond water to shrimp suitability for fish culture. Proc. Pacific Sci. Congres. 9(10):72-75.

Ward, H.B. \& Whiple, B.C. 1954. Freshwater Biology. $2^{\text {nd }}$ ed. Jhon willey and Sons. Inc. New York. 1246 pp.

Welch, P.S. 1948. Limnological methods, Mc. Graw-Hill Book Company. Inc. New York. pp. 206-216. 